\title{
ORIGINS OF THE LANGUAGE LABORATORY
}

\author{
Dr. Phillip Peterson
}

Department of Spanish \& Portuguese

Stanford University

Stanford, California 94305

It has long been held that the language laboratory stems from the 1920's, with sporadic examples reaching back to the beginning of the present century. L. G. Kelly, in his scholarly treatment of the history of language teaching, confirms this notion, "The germ of the language laboratory goes back to the 1920's."' Elton Hocking, quoting William Riley Parker, states further, "A French conversational course was produced in England on an Edison cylinder as early as 1904, and this new device was soon being tried on classes at Yale University and elsewhere."2 The language laboratory in practical form can be traced tback to the 1890's and in concept to the very inception of the phonograph.

The phonograph, invented by Thomas Alva Edison, and constructed by John Kruesi between December 1-6 of 1877, had implicit in its very nature both the preservation of languages and their practical acquisition. The Count du Moncel, writing on the presentation of the phonograph before the French Academie des Sciences on March 11, 1878, mentions in a footnote, "Suivant M. Lambrigot, les lames parlantes peuvent etre utilisees dans bien des cas; pour l'etude des langues etrangeres, par exemple, elles permettront d'apprendre facilement la prononciation, car on pourra, en les reunissant en assez grand nombre, en former une sorte de vocabulaire qui donnera l'intonation des mots les plus usites dans telle ou telle langue."3 Though in theory it would seem that we have already realized the incorporation of the phonograph in foreign language teaching, the early tin foil phonograph was little given to accuracy in sound discrimination, to wit, "We believe the phonograph is now tolerably successful in reporting spoken words - that is, provided the hearer already knows what has been said into it, and what he may, consequently, expect to hear - so that on a subject of this character the confusion of tongues at the Tower of Babel would probably be simplicity itself compared with what the machine might be made to report."4

The next ten years saw little development of this wonderous instrument, as Edison had now turned his sights to the practical development of the incandescent light. Much criticism has been leveled at Edison for his lacuna in the development of the phonograph. Music enthusiasts lament particularly the loss of recordings by Jenny Lind or of Franz Liszt. However historic perspective has cer- 


\section{Origins}

tainly shown the wisdom of Edison's decision, the result of which was electric lighting for the entire world.

Though the notions of preservation of languages as well as their learning sprang to mind immediately, the first rush of activity was in the direction of preserving the then fast disappearing African, Indian and Polynesian languages of the world. Well before the tin foil phonograph had become a practical instrument for recording sound with any sort of recognizable fidelity, scientists were anticipating precisely this usage.

In 1884, just six years after the invention of the phonograph, Doctors Zintgraff and Chavanne of Germany visited the Congo, equipped with a tin foil phonograph (See Figure 1), for the purpose of fixing the speech and melodies of unknown tribes.5

In January of 1887, Edison, having completed his work on the incandescent light, was a "free" man again. His thoughts turned immediately to what he considered his most original invention, the phonograph. In an article, Edison himself lists the preservation of foreign languages as one of the many realizable goals of the phonograph.6 It was in this year that Edison constructed his "Perfected Phonograph," which had now the quality needed for a meaningful recording of foreign language.

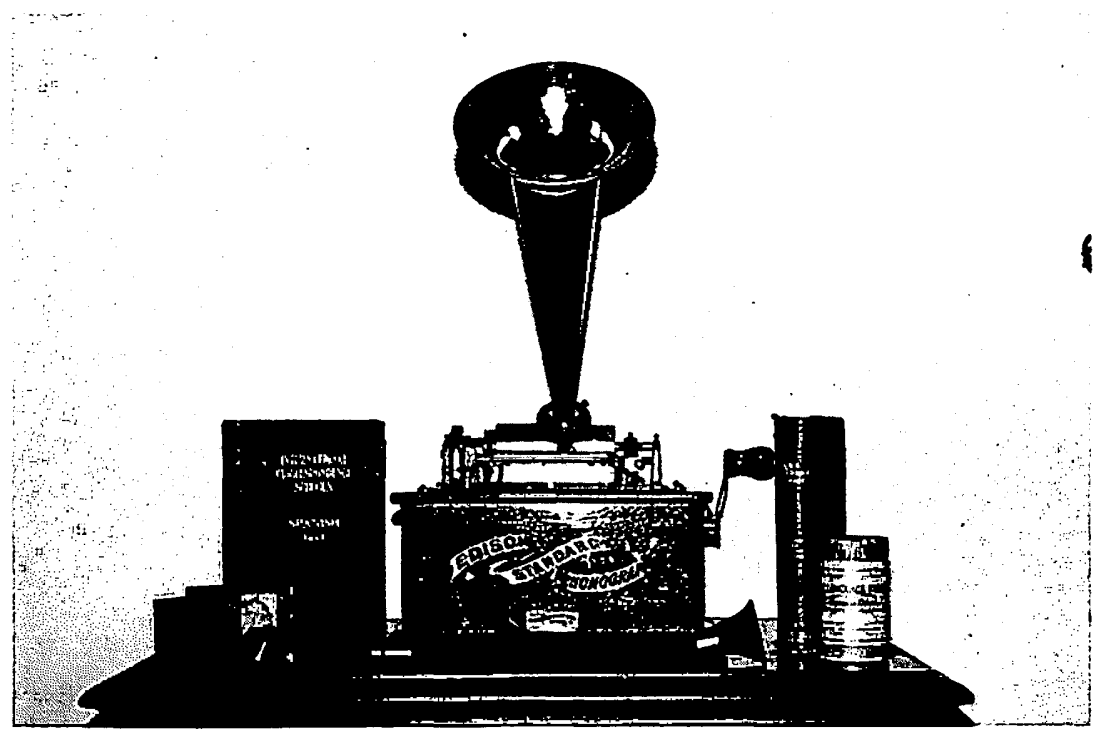

Figure 1. Edison tin foil phonograph (1878), of the type sold throughout Europe in the 1880's. From the private collection of the author. 
A few years later, J. Walter Fewkes read a paper before the American Folk Lore Society of Boston on April 19, 1890, in which he reported on his experiments in recording the songs, folk tales and languages of the Passamaquoddy Indians of New England. ${ }^{7}$ In January of 1898 , members of the native Hawaiian delegation visited the Bureau of Ethnology in Washington, D.C., to make a series of recordings of their language and traditions. At roughly the same time, a Professor Mooney, equipped with phonograph, traveled thirty thousand miles through the different states and territories of the West to secure recordings of the Indians during the ghost dance craze, recording their speech while in trance condition. He noted that the language of Indians had changed materially since their contact with English-speaking settlers. Professor Mooney made further trips to Mexico, there to study the rites of the Kiowa Indians and others. ${ }^{8}$

Though few of these early and historically important cylinders have been preserved, there do exist the cylinders reported upon in the San Francisco Examiner of November 12, 1903, in which we read of the success of Dr. A. L. Kroeber, secretary of the Department of Anthropology of the University of California at Berkeley, in recording the customs and language of the Mojave Indians on some one hundred cylinders. 9

As a further application of the phonograph, J. Walter Fewkes suggested, "It seems possible that the phonograph may be found to be of valuable assistance not only in the study of Indian, but also of all modern languages ... A number of cylinders with records of sentences pronour.ced by a Frenchman or German with the proper accent might be found a valuable aid to a teacher of these languages who is not a native of the land the language of which he is teaching. Even proficient teachers might find it a help in their classrooms."10

The first actual mention of the use of a phonograph in foreign language teaching at the college level comes from 1891, in which the College of Milwaukee is described as using an Edison phonograph in teaching French and other foreign languages. The experiment at this college is documented in the first issue of The Phonogram, "The phonograph is used in the College of Milwaukee as an aid to the Professor of Languages. It never tires, and can be made to repeat the same phrase or the same word hundreds of times. The teacher, while addressing the class, speaks into the phonograph, which in turn, repeats the lesson as often as desired."11 
In 1900, Dr. John Enicott Gardner of the Chinese Bureau of San Francisco gave two classes in Chinese for the extension work of the University of California at Berkley and at the same time a class in the University of Pennsylvania. It was reported that the class in Philadelphia was having no difficulty with the language of Canton and that oral enunciation and the important varying pitch were perfectly recorded on a series of cylinder records made by Dr. Gardner and sent to Philadelphia.12

The earliest method of teaching foreign languages, incorporating the use of the phonograph was devised by Rafael Diez de la Cortina, who established an academy of languages in New York in 1882. Though not working with the phonograph at that early date, Cortina undoubtedly started experimenting with recordings in the mid or late 1880's, if we are to take literally an announcement of the National Phonograph Company, which started in 1900, "Prof. Cortina is the originator of the adoption of the Phonograph for the teaching of languages, with an experience of fifteen years making language records." 13 This would place Cortina's experimentation at 1885 , at which time there had not yet appeared a practical Edison phonograph, however, it is exactly the year in which Alexander Graham Bell, his brother Chichester and Charles Sumner Tainter created the graphophone, a variation upon the phonograph, which was later to be Edison's ubiquitous Nemesis.

It is curious that no mention is made of Cortina's work in the early issues of The Phonogram, published from January 1891 through April 1893, even though the Rosenthal Method, the second to make widespread use of the phonograph, is well documented throughout the first year of its publication.

The earliest Cortina ads which this writer has been able to uncover date from 1893, in which the texts of the method are advertised for self-study or for use in schools. The first edition of Cortina's Spanish in Twenty Lessons marks the earliest commercial use of the phonograph in the teaching of foreign languages. This is corroborated in the following note, "Any teacher of languages, from any text-book can put the lessons upon the machine in this manner, for the benefit of the pupil. Of course, it is better if a special book is used, prepared by a teacher who has given thought to this method of study. There is a prominent Professor (Cortina) in New York, who has done this. He has been using the Phonograph in teaching French and Spanish for the past ten years."14 Cortina, after the publication of his first work, followed in fast succession with Ingles en Veinte Lecciones (1893), Modelos para cartar (1895), French in Twenty Lessons (1896), etc. Expanding his sphere of activity in 1892, Cortina instituted a plan 
to disseminate his teaching of foreign languages to all parts of the world, but especially to South America and Mexico. By this system, he would ship to the student a set of twenty cylinders to accompany the twenty lessons of the text. Accompanying these cylinders would be twenty blank cylinders on which the student would record his voice. These in turn were mailed to the school in New York for evaluation and returned to the student with commentary and correction. Here we have the true essence of the language laboratory, which serves the student, not only for self-evaluation, but for teacher evaluation as well. It is reported that by 1897 , Cortina had sent out upward of a thousand phonographs and foreign language sets. The obvious tirelessness of the phonograph in repeating phrases and drills, through the voice of native speakers, in this case that of Mr. Cortina himself, is emphasized in all the advertising campaigns of the school.

In the early years of the commercial phonograph, all recordings were orginal, as there were no duplicating methods. Soon a system of making multiple originals was devised by placing several phonographs before the performer. In the early 1890's, Edison devised a method of pantographic duplication, by which one original master might render up to one hundred and fifty duplicates. From $190^{1}$ on, duplicate records were made by Edison's gold moulder process, which ended any limitation to the number of duplicates made from an original recording.15 It would seem that the earliest of the Cortina cylinders were made individually, and early advertising of the system offers cylinders with one lesson of either the French o: Spanish series for one dollar. These were apparently made personally by Cortina in the recording room of his Academy of Languages. It is likely that from the formation of Edison's National Phonograph Company in 1896. that the Cortina cylinders, which now were advertised in sets of ten and twenty, were produced by Edison in the Edison laboratories.

Cortina has been featured consistently as the originator of the use of the phonograph in foreign language teaching. His method was granted an award at the Chicago World's Fair of 1893 for its adaptability to the teaching of fereign languages and in 1901, received the silver Medal at the Pan-American Exposition in Buffalo.

The Cortina records continue in the form of cylinders well into the present century. The earliest documented ads for the Cortina Method on discs appear in 1913. In 1908, Cortina started to use CORTINA PHONE as a trade name for his method, patterning this name after the earlier LANGUAGE PHONE of Rosenthal, which appeared in late 1901. The name CORTINA PHONE has appeared on and off until the present day. The Cortina Method is still well repre. sented in the foreign language section of any extensive bookstore. 


\section{Origins}

During the halcyon days of the Cortina Method, it was used widely in the U.S. for public and private schools and universities, in home study courses, in the Academy of Languages in New York, as well as cutside the U.S. through correspondence courses. There is evidence that many universities used the Cortina records as an integral part of their foreign language courses, or at least recommended their use outside of class for reinforcement. As an example of the latter, we read in the 1914 Reading Lists of courses given at Columbia University, the following statement, "Valuable practice in understanding spoken French is afforded by the use of a phonograph. The student must be sure, however, to choose good records, such as those of the CORTINA method."16 Though the Cortina Method first appeared in the form of foreign languages in twenty lessons written in English, by the 1920's the full impact of the Direct Method, doubtless through the increasing influence in this country of the famous method of Maximilian Bertlitz, was seen in the appearence of a series of courses written in the language being taught, such as Cortina's Espanol en Espanol, Francais en Francais, Deutsch auf Deutsch, Italiano in Italiano, etc.

Similar in many aspects, the second important method of the period, the 1890's, was devised by Dr. Richard S. Rosenthal, who, basing his method on the principles set forth by Prendergast, managed to keep the best of Prendergast's ideas at the same time eschewing his weaknesses. Rosenthal wrote his internationally famous Meisterschaft System in 1872.17 The Rosenthal Method came at a time when a great ceal of foreign larguage instruction consisted of the memorization and recitation of paradigms. Born in Potsdam, Prussia, on March 28, 1844, he became interested in the study of foreign languages early in his life. Five years after his arrival in the United States, Rosenthal was appointed general interpreter for the City and County of New York in 1872, and it is reported that at that time he had a command of twenty.eight foreign languages.

It is not likely that the first version of the Meisterschaft System was published in the year of its writing. In an early trade journal of the phonograph industry, we find this statement, "It is claimed that 550,000 copies of the book of this system (Meisterschaft System) have been issued in the past fourteen years." 18 This would place the date of first publication at 1877, which coincides roughly with a documented German edition of the work, titled, Das MeisterschaftsSystem zur praktischen u. naturgemassen Erlernung der franzosischen Geschafts. Leipzig, 1878.19 
In 1876, Rosenthal returned to Germany to form the Akademic fur fremde Sprachen in Berlin and Leipzig and somewhat later to establish Meisterschaft Colleges in Paris and London. His last year in Europe, 1880, was spent as tutor to the Royal Family of Austria, however, this was not greatly to his liking, and in 1881 he returned to the U.S. to devote the rest of his productive life to the teaching of foreign languages in Boston, Chicago and New York.

The first American version of The Meisterschaft System for French and German was published in 1881 in New York. Almost immediately, Rosenthal moved to Boston to establish a college of foreign languages there, where Spanish and Italian were added to the list of available languages. It is possible that Rosenthal did not remain in New York to establish his school there because of the impending formation of the Cortina Academy of Languages in 1882. Whatever his reasons, he remained in Boston for ten years, then moved to Chicago in 1893, where he published his Rosenthal Method of Practical Linguistry and the Physician's German Vademecum. Desipte Rosenthal's public disavowal of his former Meisterschaft System, the latter remained in active competition with Rosenthal's second work well into the first decade of the Twentieth Century.

The first evidence that Rosenthal was using foreign language records with his system is found in an early issue of The Phonogram. which commenced publication in January of 1891 . In an article by Edward D. Easton, president of the Columbia Phonograph Company, we find the following, "Our latest new work in Washington is languageteaching. Dr. Richard S. Rosenthal, the well-known author of the Meisterschaft system, has come here to work with the Columbia Company. . . The method of study is to train eye and ear at the same time... Classes of not less than ten are equipped with a phonograph for a year, ten sets of books and one set of cylinders with ten-way hearing tube, for $\$ 30.00$ each." 20 As a concession to the priority of Cortina in this field, Easton continues, "This use of the phonograph has been presented in literature for a long time, but has not been taken up practically and earnestly."21

Up to the introduction of hard wax cylinders made by the gold moulded process of Thomas Edison in late 1901, recordings were not of a lasting nature. Incised in soft brown wax, the recording soon wore down after much repetition of phrases and sentences. Despite this fact, Rosenthal continued unabated in correspondence courses, in the College of Languages in Boston and in summer courses through. out the East. As early as 1882, Rosenthal was advertising summer courses at Martha's Vineyard, Mass., offering a five-week course of instruction in French, German, Italian or Spanish under his personal direction. 22 


\section{Origins}

Though seemingly following in the footsteps of Cortina, Rosenthal devised a method which was more carefully thought out and which had many innovations, of which Cortina was unmindful. ${ }^{23}$ In his explanation of the method used in the Common Sense Method of Practical Linguistry, Rosenthal was quick to criticize the prevailing system of teaching foreign languages in the universities of the day. He decried the fact that university students, who might parse, analyze, decline, conjugate and repeat whole pages of grammatical rules and foreign words by heart, were incapable of asking for the necessities of life in idiomatic language. Rosenthal looked upon grammar as the science of language. In this he differed from the Direct Methodists of the day who had rejected grammar outright. His feeling was that when colloquial mastery preceded grammar, the explanation of grammar served the purpose of supporting speech already learned. Grammar then became a plain and simple explanation of forms and idioms already mastered. Rosenthal did not strive to copy nature. Rather, he sought to improve upon it. Linguistic method was essentially a systematic art, which, though inspired by nature, must in fact improve upon it. It must produce the same results, but in a much shorter time and by the simplest and yet most systematic means possible. Rosenthal observed that a child saturated himself in sound before trying to utter it. This observation emerges as a basic precept of the Rosenthal Method, that the ear must be addressed before the tongue. Rosenthal very correctly interpreted in addition the problem of the American student who has been eye-oriented from his early school years. This orientation is easily confirmed today in student use of language laboratories, where he seems often lost without the written text before him. Among the most important of the concepts forwarded by Rosenthal are the idea of ear training, the secondary role of writing, the de-emphasis on phonetic transcription, the importance of intonation, the use of native models, the enjoyment of learning a foreign language, practice aloud, direct association, pattern drills, short intervals of practice, the study of grammar as reinforcement, in short a total approach. It is particularly interesting that Rosenthal hit upon the method of putting phrases together by adding to the last element, "In order to master the Spanish pronunciation, we will pronunce the Spanish phrase together, beginning with the last word. We do this so that the learner may get thoroughly accustomed. not only to the pronunciation of each word, but to the Spanish intonation."24

In 1901, Rosenthal published his Language Phone Method, which was not a new method, superseding the Method of Practical Linguistry, but simply a reprinting of the excrcises of the latter in a format 
which more closely followed the cylinders of the system. The earliest reference to the appearance of the Language Phone Method is contained in The Century Illustrated Monthly Magazine of November, 1901. This, incidentally coincides roughly with the introduction of the foreign language cylinders of the International Correspondence Schools in September of $1901 .{ }^{25}$ With the appearance of the Language Phone Method, records were being duplicated by the gold moulded process, obviating the early erasure of material due to repeated use of the cylinder. The phonograph sold with the early Language Phone Method was a version of the Model Q Graphophone, adapted to the use of foreign language instruction, with an earphone attachment (See Figure 2). The introduction of the system on discs seems to be

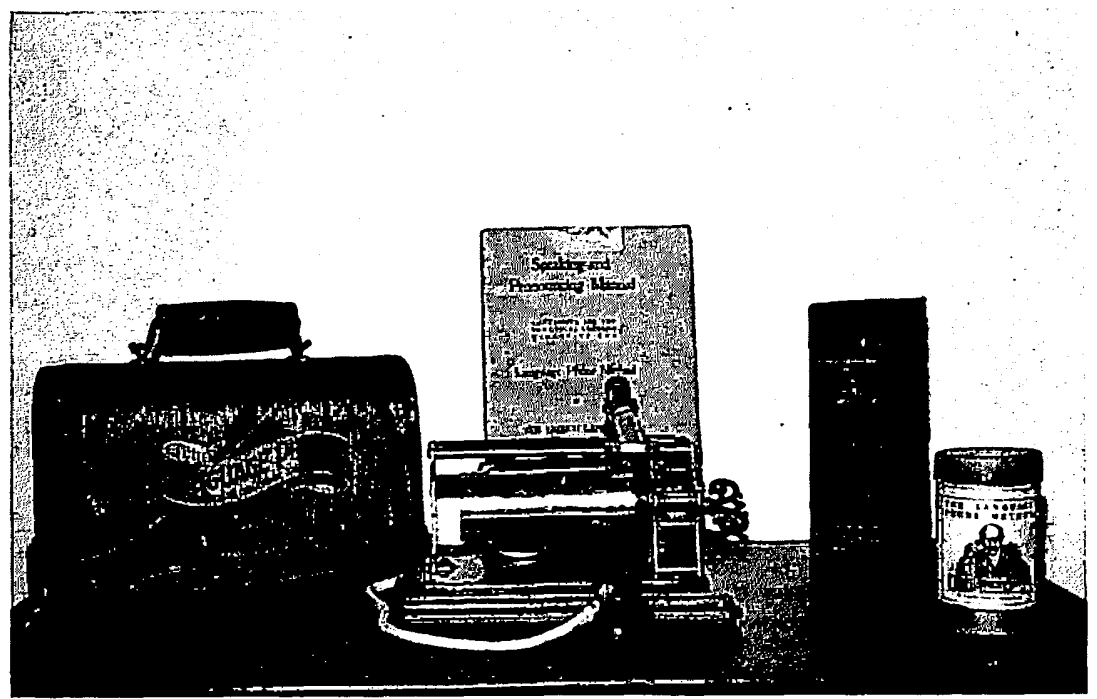

Figure 2. Rosenthal Foreign Language Outfit. From the private collection of the author.

much later, 1914 (See Figure 3). With the advent of the disc record in foreign language instruction, the invaluable aid of self recording and evaluation was laid to rest. Despite this fact, Rosenthal's method remained essentially unchanged for some seventy-five years, right up to the publication of its most recent edition in 1941, reprinted in 1947.26 


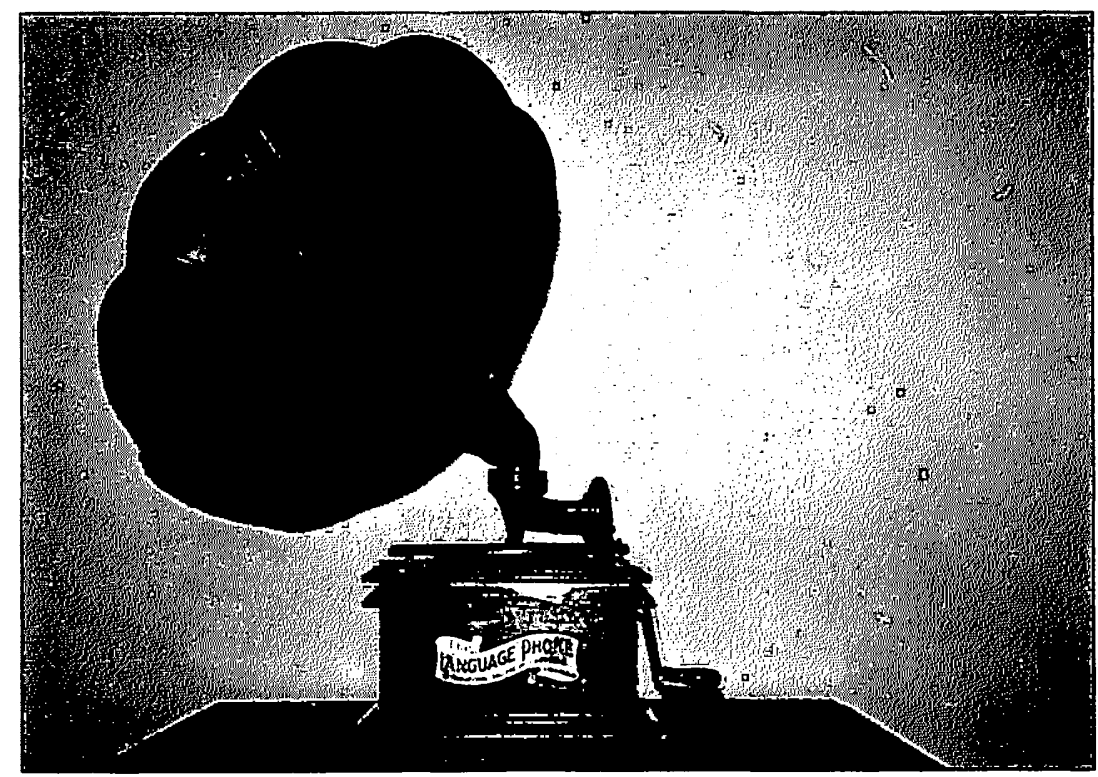

Figure 3. Rosenthal Disc Graphophone (1914). The machine was advertised for one year only, which accounts for its extreme rarity among collections today. From the private collection of the author.

A third important foreign language system was placed before the public by the International Correspondence Schools of Scranton, Pennsylvania, using the Edison phonograph and Edison cylinder records. These schools arose in this predominant mining area as a result of a plea on the part of Pennsylvania miners for special education to enable them to pass the mine-law examinations of the day. The school was established in 1891 by Thomas J. Foster, serving the needs of the miners by offering correspondence courses of instruction in coal mining. The catalogue of the school lists for the first time in late 1901 instruction courses in French, German and Spanish. The introduction of the foreign language courses in this year is further corroborated by news stories of the time and by magazine ads, the earliest of which appears in the September 14th issue of Harper's Weekly Magazine. Unlike the Rosenthal and Cortina Methods which

Though not comparable in technological sophistication, Rosenthal's early laboratory use of the phonograph had everything in common with mobile la'boratories which appeared in the 1950's and 1960 's, and which are still in use today in many schools (See Figure 4). Given the international nature of the Rosenthal Colleges of Foreign Languages, it is obvious that language laboratory usage of the phonograph was flourishing in the 1890's, though it was not to enter the elevated climes of the universities on a widespread basis until after World War II. 


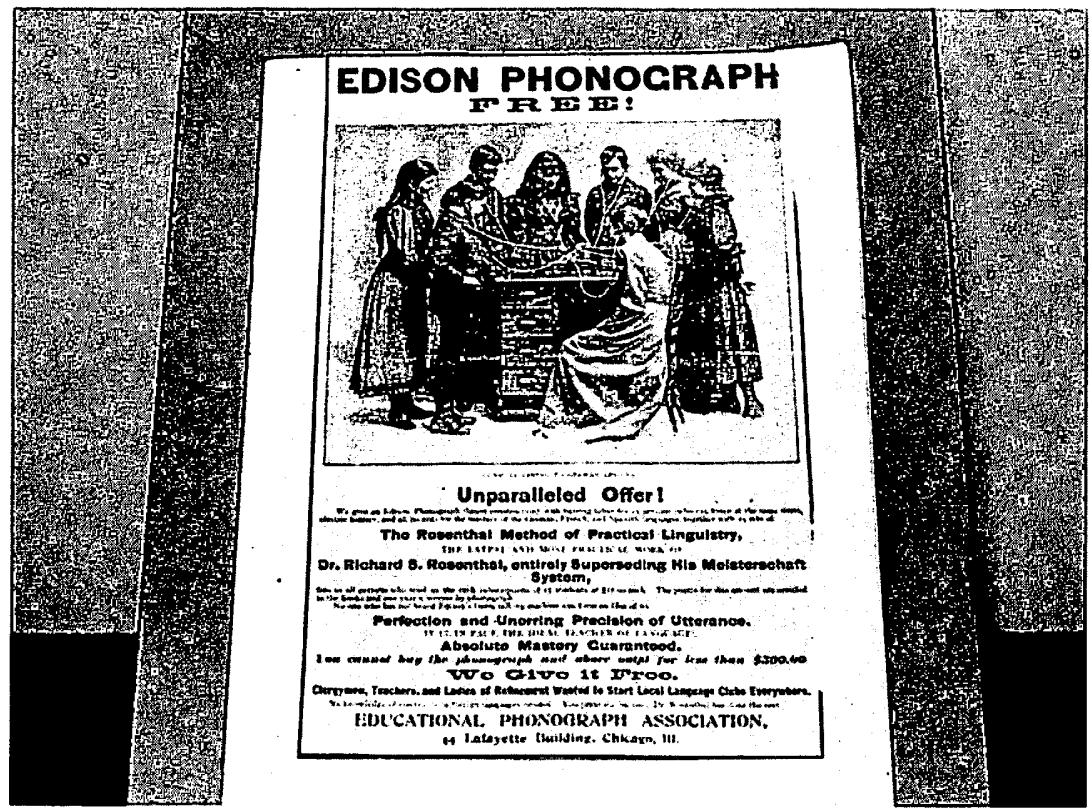

Figure 4. Group of students using the Rosenthal "mobile laboratory" of 1893. From HARPER'S MAGAZINE ADVERTISER, December 1893.

also maintained schools of languages, I.C.S. instruction was purely via correspondence. However, the methods used were similar to the then two most popular systems, in that language records, in the form of cylinders, were sent out to the student, with blanks for self recording. These recordings were then sent to the school, from which they were returned to the student with detailed correction. A specimen letter of criticism states, "We have received and examined your first record in the German Course... We have detected, however, a few mistakes in your pronunciation... Deutsch, the diphtong eu has nearly the sound of oi in "oil," but as this is not absolutely correct listen to the master records for the correct pronunciation of this sound."27

The original Phonograph Outfit, which was furnished every student enrolled in the French, German and Spanish courses at no additional cost, consisted of an Edison Standard Phonograph, Model A, equipped with a special repeating attachment, a 14-inch brass horn, Model " $C$ " reproducer, recorder, special hearing tube with headpiece attachment, a sound modifier, speaking tube, winding crank, camel's hair chip brush and two blank cylinders, one of which came in a special record mailing case (See Figure 5). 


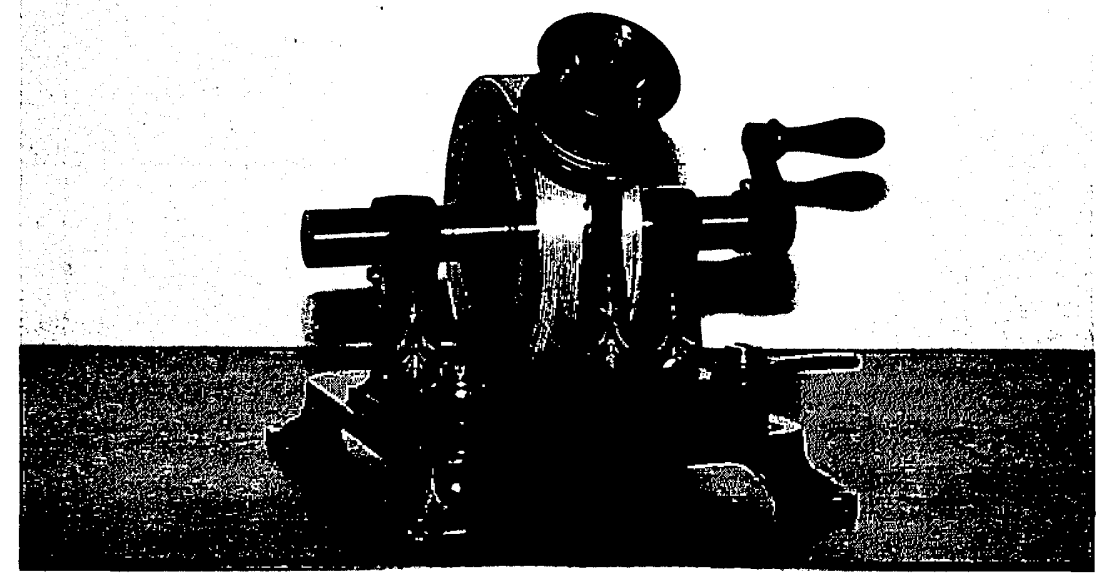

Figure 5. I.C.S. Foreign Language 0utfit. Note the repeater level on the front of the Edison phonograph for "instant replay." From the private collection of the author.

At the time of its introduction only three foreign languages were offered: French, German and Spanish, each in twenty-four cylinders. Italian was added at a later date. Though introduced at the very beginning of the gold moulded era, I.C.S. records continued well into the Blue Amberol period, which marks the introduction of celluloid cylinders by Edison in 1912. Edison, incidentally, was not the first to use celluloid in making cylinder records. The first to appear on the market were those of the Lambert Company of Chicago, which manufactured pink cylinders in 1900. It was not until 1912 that Edison, who had been experimenting with celluloid well before Thomas B. Lambert, was able to buy the process for his own use. The hiatus of twelve years during which Edison was denied use of celluloid for his cylinder records is one of myriad cases of bias in patent litigation against Edison and just another instance of the courts handing over to the competitor an invention, at the same time denying the inventor its use!

The Cortina, Rosenthal and I.C.S. were all flourishing well into the 1920's, some living past that period. Each system required as an integral part the use of the phonograph, not only for correction of pronunciation but for use in pattern drills, repetition of phrases, etc., which hopefully would lead to fluency in the language. Though these systems were outside the walls of the university, they did have their influence. From the beginning, they were advertised as applicable to use in schools and from the evidence, many schools and some universities did incorporate their features in their foreign language courses. Of the three, the Rosenthal Method most closely resembles today's linguistic approach. If we have gained little in method, we have at least advanced in technology! 
'L. G. Kelly, 25 Centuries of Language Teaching (Massachusetts: Newbury House Publishers, 1969), p. 244.

2Elton Hocking, Language Laboratory and Language Learning (Washington: National Education Association of the United States, 1964), p. 11.

${ }^{3}$ Theodose du Moncel, Le Telephone, le microphone et le phonographe (Paris: Librairie Hachette et Compagnie, 1878), p. 308.

4Scientific American, 5 April 1884, p. 208.

5The Phonoscope, 2, No. 1 (1898), 9.

6Thomas A. Edison, "The Perfected Phonograph," The North American Review, June 1888, p. 646.

7See Science, 2 may 1890, pp. 267-269.

8See The Phonoscope, 2, No. 1 (1898), 9.

9See The Antique Phonograph Monthly, 1, No. 1 (1973), 2.

${ }^{10 S c i e n c e, ~} 2$ May 1890, p. 269.

"The Phonogram, 1, No. 1 (1891), 11.

${ }_{12}$ See The Phonoscope, 4, No. 5 (1900), 1.

13National Phonograph Company, The Phonograph, May 1900, p. 48.

14The Phonoscope, 3, No. 6 (1899), 11.

15See Allen Koenigsberg, Edison Cylinder Records, 1889-1912 (New

York: Stellar Productions, 1969), pp. xvii-xxiii.

16Adolph Edwards, Language Logic (New York: The Trow Press, 1917), p. 39.

17See Richard S. Rosenthal, A Card from Dr. Richard S. Rosenthal (Chicago: Polyglot Book Company, 1894), p. 4.

18The Phonogram, 1, No. 5 (1891), 118.

19Wilhelm Heinsius, Allgemeines Bucher-Lexikon 1875-1879, 2nd ed.

(Graz: Akademische Druck u. Verlagsanstalt, 1963), p. 367.

20See The Phonogram, 1, No. 2 (1891), 53.

21loc. cit.

2See The Nation, 6 July 1882 , ad section.

23See National Phonograph Association, Proceedings of the Fourth Annual Convention of the National Phonograph Association of the U.S. (Chicago: The Linotype Reporting and Printing Co., 1893), pp. 35-47.

24Richard S. Rosenthal, Revolution in the Mastery of Languages: Languages by Phonograph (Chicago: Polyglot Publishing Company, 1894), p. 12.

2sSee Phillip Petersen, "The Orgin of the I.C.S. Cylinders," The Antique Phonograph Monthly, 1, No. 4 (1973), 3.6.

26See Richard S. Rosenthal, Spanish Self Taught: Rosenthal's Common-Sense Method of Practical Linguistry (Garden City: Garden City Publishing Co., Inc., 1941).

27International Correspondence Schools, German: A Unique and Practical Method of Learning to Speak, Read, and Write the German Language (Scranton: International Textbook Company, 1909), p. 14. 